\title{
THE ROLE OF TOURISM IN EUROPEAN UNION - SELECTED ISSUES
}

\begin{abstract}
The article presents an outline of European touristic policy and the role of tourism sector in European economy. Statistical data show the importance of European tourism as the number one tourist destination worldwide. Institutions of EU involved with tourism (such as the European Parliament - Committee on Transport and Tourism, the European Commission - DG Enterprise and Industry: Tourism section) shall put more emphasis on some specific issues as there is no specific tourism policy and development programmes in this matter. An urgent consideration must be given to a proper touristic service marketing by enhancing promotion programs, taking patterns from successful experiences of other countries, using modern marketing tools taking inspiration from new emerging tourism markets worldwide.

The author shows the possibilities and prospects that internal market gives to the tourism of Member States. Community actions and measures are aimed at strengthening the position of European tourism. Moreover challenges and opportunities of European compared to world tourism are described.
\end{abstract}

KEYWORDS: European Union, travel, leisure, policy, legislation.

\section{INTRODUCTION}

Tourism plays an important role in contemporary world in the sphere of economic, social, educational and even political activity. It is a transmitter in shaping attitudes towards culture, art, nature, health, physical and mental condition of the whole society Szejniuk, 2014, 313-326). 
Tourist activity is an indicator of the quality of life of residents and the country's development. Tourism has a major impact on the use of space and infrastructure, creates employment and increase regional development (Majewska, 2005, 219).

The highly variable nature of tourism, particularly its vulnerability to change due to fashion, trends requires that public and private sector interests try to understand this fluctuation to attract tourists (Page, 2011, 344). There are many trends in different interrelationships affecting each other such as: consumer behaviour, political change, globalization, climate change etc that have a significant impact on the European and global tourism (Cooper, Fletcher, Fyall, Gilbert, Wanhill, 2008, 659). The importance of public discussion for civil society is focused on a vertical relationship. In other words, the citizen occupies the lower layer, and the state occupies the upper layer. Most individual lives are vertical (Eroğlu, 2011, 60).

\section{EUROPEAN TOURISM IN STATISTICAL TERMS AND AS A PART OF INTERNATIONAL TOURISTIC SECTOR}

Tourism is an important contemporary sphere of economic activity, while also it is the sphere of social activity. Tourist activity is one of the basic measures of living standards and an indicator of the development of societies.

International tourist arrivals grew for the seventh consecutive year to reach 1.2 billion, a sequence of uninterrupted growth not recorded since the 1960 s. The strongest growth was recorded in the Africa and Asia and the Pacific regions. International tourist arrivals reached 1,235 million in 2016, which is an increase of $4 \%$ compared to the previous year. Tourism has grown above average, at $4 \%$ yearly for 7 years in a row. 300 million more people travelled internationally for tourism between 2008 and 2016.

Among 5 world's top tourist destinations three are EU member states: France (84,5 million international tourist arrivals in 2015), Spain (68,5 million), Italy (20,7 million). 
Graph 1.

International tourist arrivals 2016

Middle East; 4\%

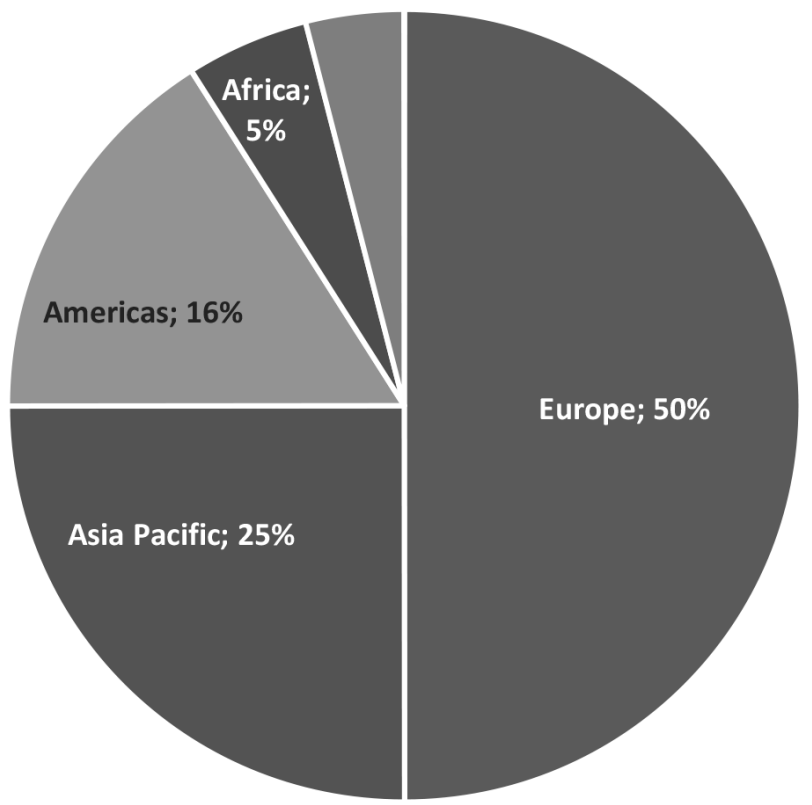

\begin{tabular}{|c|c|c|c|c|c|}
\hline region & Europe & Asia Pacific & Americas & Africa & Middle East \\
\hline share & $50 \%$ & $25 \%$ & $16 \%$ & $5 \%$ & $4 \%$ \\
\hline million & 615 & 309 & 200 & 58 & 54 \\
\hline
\end{tabular}

Source: own calculations based on UN WTO (2017) Annual Report 2016 (UN WTO, 2017, 12)

According to the UNWTO, Europe was the most frequently visited region in the world in 2016, accounting for over half (50\%) of all international tourist arrivals, equivalent to some 615 million persons. The wealth of European cultures, the variety of its landscapes and the quality of its tourist infrastructure are likely to be among the varied reasons why tourists choose to take their holidays in Europe. The number of overnight stays in tourist accommodation, which reflects both the length of stay and the number of visitors, is considered a key indicator for tourism 
statistics. In 2014, there were 2.68 billion nights spent in EU-28 tourist accommodation. This figure marked a $1.5 \%$ increase when compared with 2013 (with similar rates of change for both residents and non-residents) (Eurostat, 2016, 179).

According to the definition of tourism i.e. tourism sector includes traditional providers of transport and tourism: hotels, restaurants, cafes, travel agencies, car rentals, airlines etc. who provide goods and services directly to visitors currently represents about 3,1\% of world GDP while total contribution reaches $10,2 \%$ world GDP which represents $9,6 \%$ employment (World Travel \& Tourism Council, 2017, 7).

Travel receipts in balance of payments in real prices in 2018 (estimated) amounts to 760,1 billion USD which consists of internal tourism consumption plus purchases by tourism providers, including imported goods, representing 3,6\% of European GDP according to World Travel \& Tourism Council based on The UN Statistics Division-approved Tourism Satellite Accounting methodology (TSA:RMF 2008). However, indirect contribution to GDP is much higher - tourism indirectly generates $9,9 \%$ of EU GDP and provides about 9,8\% of all workplaces (World Travel \& Tourism Council, 2018, 7). Tourism is particularly important when it comes to offering job opportunities for young people, who represent twice as much of the labour force in tourism than in other sectors of the economy (COM 2007 498). Employment growth in the tourism sector in recent years has been much higher than in other sectors of the economy. This sector contributes significantly to achieving the Lisbon Strategy goal that is to create more and better jobs. The importance of tourism for the EU economy is likely to grow even more in the coming years.

\section{EU REGULATIONS CONCERNING TOURISM}

Until the adoption of the Maastricht Treaty, there were no provisions relating to tourism in the founding treaties. The first records of tourism - have been introduced to the Treaty establishing the European Community signed in Maastricht. According to article 3 in order to achieve the objectives of the Community, the activities of the Community include, inter alia, "measures in the spheres of energy, civil protection and tourism." The above provision 
does not entitle to take up a common tourism policy, but it highlights the importance of tourism in the basic objectives of the Community. The Treaty of Amsterdam and Nice have not introduced any changes in this respect. The Lisbon Treaty also does not include tourism to the areas covered by the common policy, however, expands the powers of the Union in this area. According to the Art. 6 of the Consolidated Version of the Treaty on European Union, the Union have competence to carry out actions to support, coordinate or supplement the actions of the Member States in the field of tourism. Moreover, the Treaty introduces a separate title on tourism (Title XXII), containing Article 195, under which: "The Union shall complement the action of the Member States in the tourism sector, in particular by promoting the competitiveness of Union undertakings in that sector." The Lisbon Treaty creates a new basis for the development of tourism, stating that the EU has to become the major tourist destination in the world.

\section{Selected Community documents AND ACtions CONCERNING TOURISM:}

29 September 1990 - Informal Conference of Ministers of Tourism on European tourism policy in Milan

7 February 1992 - Maastricht Treaty

3-14 June 1992 - United Nations Conference on Environment and Development (called Earth Summit) in Rio De Janeiro

1 January 1993 - Fifth Programme for the Environmental Protection. Selected areas: transport, agriculture, energy, tourism, industry

5 December 1993 - Commission's White Paper Growth, competitiveness, employment - the challenges and ways forward into the 21 st century 14 April 1995 - Green Paper - The role of the Union in the field of tourism 4 December 1996 - The First Multiannual Programme For European Tourism «PHILOXENIA» for 1997-2000

2004 - creation of TSG - Tourism Sustainability Group created by European Commission. The group consisted of experts of international organizations, experts nominated by governments, representatives of the tourism industry, local authorities, trade unions, NGOs and researchers 
February 2007 - TSG report: Action for more sustainable European Tourism 19 October 2007 - Communication from the Commission - Agenda for a sustainable and competitive European tourism. All stakeholders have to work towards sustainability and competitiveness of Europe as the most attractive tourist destinations.

\section{December 2007 - Lisbon Treaty}

7 October 2008 - Declaration on the European Destinations of Excellence Network for sustainable tourism (EDEN)

30 June 2010 - Communication from the Commission to the European Parliament, the Council, the European Economic and Social Committee and the Committee of the Regions - Europe, the world's No 1 tourist destination - a new political framework for tourism in Europe (COM/2010/0352)

The lack of the legal basis for a common tourism policy in treaties means that, in accordance with the principle of subsidiarity, is area reserved for the competence of the Member States. So, if there is a need to take on any action at EU level to support the development of tourism, the permission for such activities must be expressed by all Member States.

Inter-sectoral nature of tourism means that its scope covers other policies of both horizontal and sectoral levels. First of all, tourism is one of the sectors of the economy and therefore is subject to internal market policy. To ensure the proper functioning of the market, especially when there is a need to remove barriers to the creation and development of, the Treaty (Article 94) authorizes the Community authorities to take action in the field of harmonization of law, and to take other action (Art. 308). However, in such cases, consent of all Member States is required.

Activities conducted within the framework of the implementation of other policies such as transport, environment, regional, rural consumer protection are also relevant for tourism. Linking tourism with many areas of Community action raises the need for their coordination, necessary to ensure that the needs of tourism will be taken into account when adopting policies and actions in related areas (MSiT, 2009, 2). 


\section{EU INSTITUTIONS RESPONSIBLE FOR TOURISM}

The European Parliament - Committee on Transport and Tourism (TRAN) is a law making Committee under the co-decision procedure, being an equal partner in formulating transport legislation, tourism policy and policies relating to postal services.

Its scope of interests covers i.a. regional aspects of the impact of tourism in coastal regions, climate change, to some extent tourism and transport.

The European Parliament is one of the EU's main law-making institutions - it debates and passes law. However, as tourism is a sector not covered by European common policy, the European Parliament does not directly have an impact on tourism itself.

Some of the authors claim that the lack of uniform tourism policy has a negative influence on the sector. "Despite the positive outlook, (...) only a relatively small number of Members of European Parliament (MEPs) are actively involved in tourism, because it falls under the auspices of the member states. MEPs were frugal in investing their time and resources in tourism, because they knew that any recommendation they made were not binding for member states. Consequently there were gradually fewer and fewer MEPs actively interested in tourism and in return fewer voices in favour of tourism." (Anastasiadou, 2006, 25) Four main weak points are mentioned: no competence, sponsorship, framework-policy, common promotion.

On the other hand some EU member states see the lack of tourism policy as a strong point. For example Britain has chosen to allow the free-market economy to operate in the tourism field. Since British travel and tourist interest have become subject to EU legislation, any constraints of trade have been largely abolished, allowing travel firms to compete within EU on an equal footing without legal hindrance (Holloway, 2009, 534).

European Commission's Tourism Advisory Committee (TAC) - The purpose of the TAC is to exchange information among EU Member States and Candidate countries in the field of tourism, to consult and provide the opportunity to present the country's position by drawing up guidelines on the latest European tourism policy, introducing Europe as a tourist region, addressing the most relevant tourism-related issues, and adopting communications from the European Commission. The output of its work is annual reporting of the member states. 
European Travel Commission (ETC) - The ETC has its headquarters in Brussels and has 33 members. The key objective of the organization is to market European countries worldwide. It is financed by the European Commission from funds contributed by its Member States.

The European Commission: DG Enterprise and Industry: Tourism section.

Its main activities are coordinating such projects: Destinations of Excellence, Tourism Sustainability Group, Sustainability and Competitiveness, Tourism Satellite Accounts, Social Tourism, Tourism Accessibility, Quality in Tourism Products.

The European Economic and Social Committee - there is no clear indication that the scope of activities includes also tourism. It is included in other activities, such as Group III- Various Interests Group: NAT: Agriculture, Rural Development and Environment, SDO: Sustainable Development Observatory.

The Committee of the Regions: Commission for Sustainable Development (DEVE) - Tourism is among its main 8 competencies. (CEEWEB, 2012 and Sitek, 2010, 153)

There a plenty of EU instruments ensuring the smooth functioning of the tourism sector in Europe:

- guidelines for Member States and institutions related to this sector - green papers, agendas,

- co-organized tourist Forums (European Commission-Member State holding the Presidency)

- promotion of best practice,

- EMAS - voluntary observance the standards

- environmental impact assessment (strategic investment),

- ecolabelling,

- Structural Funds - the Norwegian Financial Mechanism EEA Financial Mechanism and the LIFE + program,

- national strategies for the development of the tourism sector,

- EDEN,

- support for organizations and associations active in the development of tourism (see Kamieniecki and Sitek, 2009, 14). 


\section{COURSES OF ACTION AND CHALLENGES FACING EUROPEAN TOURISM}

According to the Lisbon Strategy European tourism policy should be complementary to the policies pursued by Member States. The main objectives of this policy are:

- improve the competitiveness of the European tourism industry,

- creating more and better jobs through the sustainable growth of tourism in Europe and worldwide.

Instruments for the implementation of this policy are:

- coordination of activities within the Commission,

- cooperation at the national level with stakeholders,

- taking actions to support the development of tourism at the Community level.

The main challenges facing the European tourism are:

- changes in the demographic structure of Europe. A systematic increase in the number of elderly people (65 years and over) will result in an increase number of travellers over the age of 50 years;

- changes in the demand for tourist services. It is expected that the most significant growth will be noticed in health tourism and tourism related to cultural and natural heritage. Moreover, the traditional $3 \mathrm{~S}$ tourism (sea, sun, sand) is being replaced by $3 \mathrm{E}$ (entertainment, excitement, education), therefore new trend of scientific tourism is growing (Sokolova, 2016, 89);

- increased competition in the global tourism market. Although Europe is still the most visited region in the world, the number of international tourist arrivals grow at a lower rate than the global average. New, competitive destinations are merging and developing, with innovative products and services, which will further increase the competition the EU tourism at a global scale. One of the main European competitor destination is, closely located, Turkey (Sitek, 2007, 9-17);

- the need for sustainability. It is widely recognized that tourism can become a victim of its own success if it does not develop in a sustainable 
way. Biodiversity, ecosystem, natural resources and non-renewable cultural heritage or even the functioning of urban areas may be threatened by the uncontrolled development of tourism. Economic, social and environmental sustainability are key factors affecting the competitiveness of tourist destinations and the prosperity of its inhabitants, as well as job creation and preservation and enhancement of natural and cultural attractions.

To meet these challenges, Europe must focus its efforts on improving its competitiveness. It is expected that more competitive tourism industry and sustainable destinations will contribute to the success of the Lisbon strategy, the satisfaction of tourists and to secure Europe's position as the Number 1 tourist destination in the world.

The sustainable competitiveness of tourism destinations is the capacity to generate high or growing well-being for residents and tourists safeguarding the assets. It depends on resource endowments (assets), resource deployment (the capacity to use those assets) and innovation (Magliulo, 2014, 21).

\section{ACKNOWLEDgements}

The complexity of tourism and the broad diversity of involved actors require the collaboration of all stakeholders involved in the planning and implementation of relevant policies and measures at European level. Community institutions, national administrations, professional organizations, employers and employees, NGOs and researchers, should build partnerships at all levels to improve the competitiveness of European tourism and demonstrate the important role. Development of cooperation and partnership under the renewed policy should be reviewed regularly during the European Tourism Forums. 


\section{References:}

Anastasiadou C. (2006) Tourism and the European Union [in:] Hall D., Smith M., Marciszewska B. (2006) Tourism in the new Europe. The Challenges and Opportunities of the EU Enlargment, UK, ISBN 9781845931179

World Tourism Organization UN WTO (2017) Annual Report 2016, available at: http:// cf.cdn.unwto.org/sites/all/files/pdf/annual_report_2016_web_0.pdf (17.06.2018) ISBN 9789284418718

Cooper C., Fletcher J., Fyall A., Gilbert D., Wanhill S., (2008) Tourism. Principles and practice, Milan, Italy ISBN 9781408200094.

Eroğlu, S. E. (2011). From Civil Society to Global Civil Society, International Journal of Arts and Sciences, 4(3) ISSN 1944-6934.

Eurostat, Eurostat regional yearbook 2016 edition, 2016 , Belgium, available at: http://ec.europa.eu/eurostat/documents/3217494/7604195/KS-HA-16-001EN-N.pdf/76c007e9-6c1d-435a-97f8-e5ea700aa149 ISBN 978-92-79-60090-6 (17.06.2018)

Holloway J. C. (2009) The Business of Tourism, Malaysia ISBN 9780273717102.

Kamieniecki K. Wspólnota Europejska a turystyka, available at: http://natura2000. org.pl/imgekoprojekty/file/Szkolenia/Kamieniecki_K-szkolenia-ue_a_turystyka. pdf (25.03.2014)

Magliulo A. (2014) Sustainable and competitive tourism: targets, determinants and measurement systems [in:] Tourism Research in a Changing World (ed.) Dias F., Kosmaczewska J., Dziedzic E., Magliulo A., Portugal ISBN 9789899896505.

Majewska M. (2005) The report on touristic activity of Poles and Rother citizens of European Union [in:] Siwiński W., Tauber R. D., Mucha-Szajek E. (2005) Hotelarstwo, rekreacja, turystyka. Kierunki przemian w świecie postindustrialnym, Poznań, Poland ISBN 8388537334.

Ministry of Sport and Tourism (MSiT) Tourism Department (2009) Turystyka w strukturach Unii Europejskiej. Programy Unii Europejskiej dotyczące rozwoju turystyki. Przyszłość turystyki w Unii Europejskiej, Warsaw, Poland.

Page S. J. (2011) Tourism Management. An introduction, Spain ISBN 9780080969329.

Sitek M. (2009) Ecological education of Tourists in the light of European Union Regulations, as the Chance for Social Science Development, [in:] Regional formation and development studies, Journal of Social Sciences No.3(4); 3/2010, Klaipeda, Lithuania ISSN 2351-6542. 
Sitek M. (2010) Instytucje i organy Unii Europejskiej w świetle postanowień Traktatu Lizbońskiego, Józefów, Poland ISBN 9788393010240.

Sitek P. (2007) Administracyjne i kulturowe aspekty przystąpienia Turcji do Unii Europejskiej, , Kirikkale, Turkey ISBN 97897501411904.

Sokolova S. (2016) Turystyka naukowa jako specyficzna forma rynku spotkań a biznesowych czy nowy rodzaj turystyki?, Turystyka i Rozwój Regionalny 6/2016 Warszawa ISSN 2353-9178.

Szejniuk A. (2014) Równowaga praca - życie osobiste, Journal of Modern Science 2/2014 vol. 21. Józefów ISSN 1734-2031.

World Travel \& Tourism Council (2017) Travel \& Tourism Economic Impact World 2017, available at: https://www.wttc.org/-/media/files/reports/economic-impactresearch/regions-2017/world2017.pdf (17.06.2018)

World Travel \& Tourism Council (2018) Travel \& Tourism Economic Impact Europe 2018, available at: https://www.wttc.org/-/media/files/reports/economic-impactresearch/regions-2018/europelcu2018.pdf (17.06.2018).

\section{Legal acts}

COM (2007) 498 final, Communication from The Commission to The European Parliament, The Council, The European Economic and Social Committee and The Committee of the Regions "Promoting young people's full participation in education, employment and society", Brussels, 5.9.2007

COM/2010/0352, Communication from the Commission to the European Parliament, the Council, the European Economic and Social Committee and the Committee of the Regions - Europe, the world's No 1 tourist destination - a new political framework for tourism in Europe, Brussels, 30.06.2010 